\title{
RURAL FLASH-FLOOD BEHAVIOR IN GOUYAVE WATERSHED, GRENADA, CARIBBEAN ISLAND
}

\author{
R. A. Pratomo ${ }^{a, b}$, V. Jetten ${ }^{a}$, D. Alkema ${ }^{a}$ \\ a Faculty of-Geo Information Science and Earth Observation (ITC), University of Twente, Enschede, The Netherlands \\ ${ }^{b}$ Urban and Regional Planning Department, Tadulako University, Palu city, Indonesia
}

Article Info:

Received: 11 August 2016

in revised form: 26 September 2016

Accepted: 03 October 2016

Available Online: 31 October 2016

\section{Keywords:}

Gouyave watershed, modelling, OpenLISEM, rural, flash-flood behavior

\section{Corresponding Author:}

Rahmat Aris Pratomo

University of Twente and Tadulako

University, Indonesia

Email: arispratomo05@gmail.com
Abstract: Flash-flood is considered as one of the most common natural disasters in Grenada, a tropical small state island in Caribbean Island. Grenada has several areas which are susceptible to flooding. One of them is Gouyave town which is located in the north-west of Grenada. Its land-use types are highly dominated by green areas, especially in the upper-part of the region. The built-up areas can only be found in the lower-part of Gouyave watershed, near the coastal area. However, there were many land conversions from natural land-use types into built-up areas in the upper-part region. They affected the decrease of water infiltration and the increase of potential run-off, making these areas susceptible to flash-flood. In addition, it is also influenced by the phenomenon of climate change. Changes in extreme temperature increase higher potential of hurricanes or wind-storm, directly related to the potential escalation of flash-flood. To develop effective mitigation strategies, understanding the behavior of flash-flood is required. The purpose of this paper was to observe the behavior of flashflood in Gouyave watershed in various return periods using OpenLISEM software. It was used to develop and analyse the flash-flood characteristics. The result showed that the climatic condition (rainfall intensity) and land-use are influential to the flash-flood event. Flash-flood occurs in 35 and 100 years return period. Flash-flood inundates Gouyave's area in long duration, with below $1 \mathrm{~m}$ flood depth. The flood propagation time is slow. This condition is also influenced by the narrower and longer of Gouyave basin shape. To develop flash-flood reduction strategies, the overall understanding of flash-flood behavior is important. If the mitigation strategy is adapted to their behavior, the implementation will be more optimum.

How to cite (APA 6th Style):

Pratomo, R. A., Jetten, V., \& Alkema, D. (2016). Rural flash-flood behavior in Gouyave watershed, Grenada, Caribbean Island. Geoplanning: Journal of Geomatics and Planning, 3(2), 161-170. doi:10.14710/geoplanning.3.2.161-170

\section{INTRODUCTION}

Flood is among the common, frequent and widespread natural disasters (Patra, Kumar, \& Mani, 2016). It can be defined as the overflowing of streams or other water bodies or accumulated water over areas which are not normally immersed. It mostly occurs in the coastal areas or those close to rivers, low land areas, and other areas highly prone to flooding. Flood can be categorized into urban, flash, coastal, river, and sewer floods (Kourgialas \& Karatzas, 2011). Also, more than fifty percent of the total population in the world inhabits low land near the rivers or coastal areas that are highly exposed to flash-flood (Mhonda et al., 2013).

Flash flood usually occurs after intense rainfall in small river basins with specific geological formations such as high slopes and low permeability. Creutin \& Borga (2003) identified flash flood as a hydrological phenomenon which rapidly flows and in which water can reach a peak level in less than 64 hours. It makes flash-flood always suffering the people, causing human casualties and property loss, and also damaging the built-environment and urban infrastructure. 
Niles (2010) and GFDRR (2010) declared that some locations in Grenada have a high susceptibility to flash-flood. Susceptibility refers to locations where the hazard events potentially occur, which is determined by local terrain conditions (Santangelo et al., 2011). Charlotte River's downstream area in Gouyave watershed, Grenada, Caribbean Islands is the example of a susceptible area. This river divides the downstream areas into two parts, i.e., upper and lower parts. The flood impacts not only occur locally, but it may correspondingly affect the whole area of the river basin. Gouyave locations which pointed out the flood conditions and flood susceptibility area are shown in Figures $\mathbf{1 a}$ and $\mathbf{1 b .}$

Many floods are caused by precipitation (duration, intensity, phase, timing, or amount). Also, certain floods are caused by temperature as in snowmelt floods (sometimes enhanced by rain or ice jams), river flooding caused by extreme tide events or storms and intense rain generating fluvial floods in large basins (Kundzewicz et al., 2014). Portugués-Mollá et al. (2016) highlighted that flash-flood could be the consequence of intense rainfall episodes concentrated extremely in place and time leading to the activation of hydro-geomorphic high-intensity processes. The changes in precipitation patterns expected for the following decades as well as urban growth, and higher population and assets densities, increase the risks of urban and sewer flooding (Gaitan et al., 2015; Kourgialas \& Karatzas, 2011). The intense heavy rainfall is a combination effect of rapid urbanization and climate change (Kundzewicz et al., 2014; Yin et al., 2016). Furthermore, the human interventions in land-use, the rate of urbanization, and the presence of dams, reservoirs and dykes increase the susceptibility of flooding, especially in large cities and urbanized areas.

Flash-flood in Gouyave watershed was caused by the heavy local rainfall. In 2011, the rainfall intensity during the rainy season in Gouyave watershed was $250-350 \mathrm{~mm}$. In some areas, the high rainfall intensity was triggered by hurricanes and tropical storms. Moreover, land-use characteristics also influence flashflood. Gouyave watershed mainly consists of natural land-use types such as forest, bare, mix-trees, and agriculture lands which usually represent the typical of the rural area. Most of the upper-part of Gouyave watershed is still forested. Approximately, the built-up area covers $5.33 \%$ of Gouyave watershed.

Figure 1. (a) Flash-flood event in Gouyave watershed in 2011 and (b) Identified potential areas of flood propagation in Gouyave watershed (Pratomo et al., 2016)
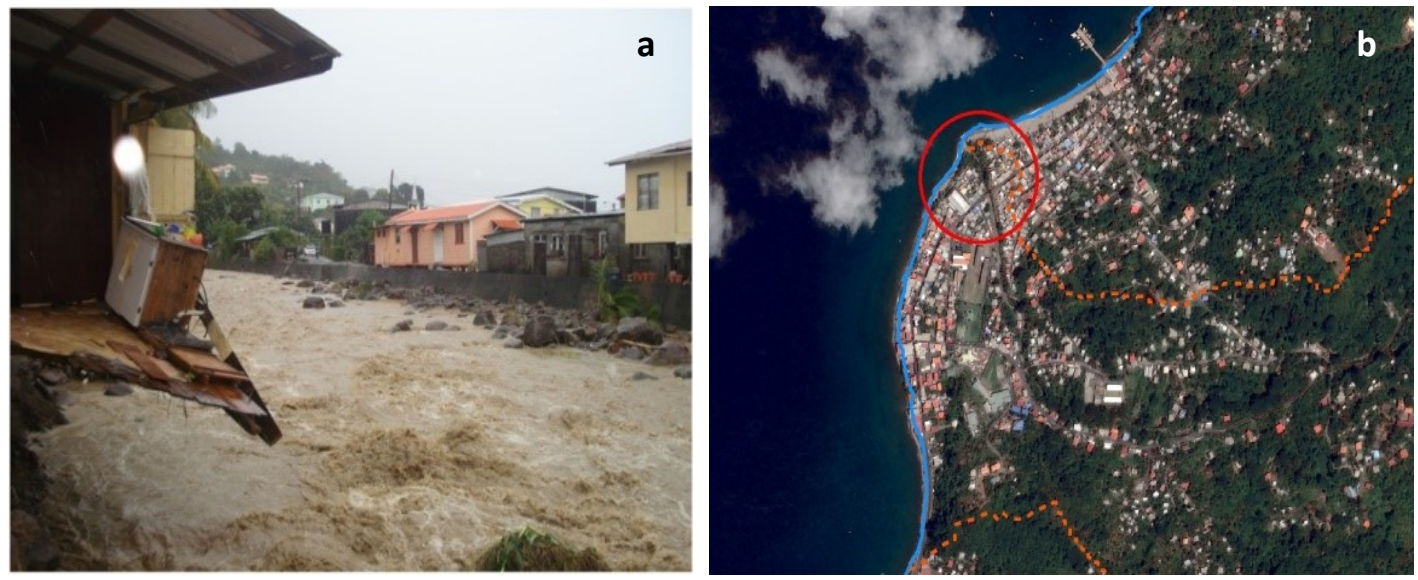

Alongside with Gouyave's regional development, the impacts of flash floods likewise affect the development of this area as a tourism destination. The related activities and supported-infrastructures could be obstructed due to the Gouyave's susceptibility to flood influenced by climatic condition (rainfall) and land-use. Cooper \& Opadeyi (2006) in their research explained susceptible flash-flood areas specifically in Grenada. Furthermore, The Caribbean Disaster Emergency Response Agency (CDERA) (2003) identified the flash-flood areas and developed mitigation actions for reducing the impacts of flash-flood events. Those studies have not clearly explained the flash-flood behavior which is important to determine the mitigation actions. 
An analysis related to physical and non-physical characteristics and conditions of flood susceptibility areas is needed to develop flood mitigation actions. The analysis of flood hazard combines a Hydrological Modelling System (HEC-HMS) and the Iber 2D hydrodynamic model to find out the flash-flood risk areas. Furthermore, the assessment of the social vulnerability and designed measures are to be placed into practice and implementation (Bodoque et al., 2016). Yin et al. (2016) generated the ensemble rainfall scenarios to evaluate the potential impacts and risk of pluvial flash-flood. The authors identified the impact and risk of pluvial flash flooding on intra-urban road networks through an integration of pluvial flood numerical modelling, GIS-based road failure analysis, and risk assessment model. Flash floods result from a complex interaction among hydro-meteorological, hydrological, and hydraulic processes across various spatial and temporal scales. A flash flood and gravel bed load transport are two keys relative problems in mountain river engineering. A case study on the mechanism of a flash flood disaster induced by bed load transport for a hydropower station in Sichuan Province has been conducted (Cao et al., 2008). In order to find-out criteria for flash flood selection, a high intensity of triggering rainfall and flood response and availability of high-resolution reliable data are used, so that the characteristics of flash floods in various morphoclimatic regions of Europe can be determined and summarized (Marchi et al., 2010). Then, the integration between physical and social vulnerability was needed to measure the vulnerability which focuses on residential buildings as exposed to flash-flood (Karagiorgos et al., 2016).

The sustainability of Gouyave watershed area is threatened by flash-flood. A development of Gouyave watershed area should be balanced with disaster mitigation actions which are synchronized with the natural environments and can respond to the flash-flood disasters. To close this gap, it is required to understand the overall flood characteristics in Gouyave watershed area, as a location which is rarely observed for research about flash-flood. This research also used some variation of return periods, as an important part of developing rainfall scenario which is further used to determine flash-flood modelling. The aim of this paper was to determine the behavior of flash-flood in Gouyave watershed in various return periods that will be valuable to support and develop disaster risk reduction strategies reducing the flashfloods impacts.

\section{DATA AND METHODS}

The method used in this paper was a modeling approach using the OpenLISEM software. Flood modeling contributed to the reduction of the flash-flood impacts and to the reduction of the uncertainty conditions in the flood-susceptibility areas. According to Jetten (2014), OpenLISEM is a model for natural hazard event and widely used for a single rainfall event to simulate flash floods, runoff, and also erosion. It can be used for integrated catchment management on small to medium scales (equals $300 \mathrm{~km}^{2}$ and less) and for simulation processes in detail in space and time.

Data collection processes were divided into 2 steps (pre-fieldwork and fieldwork). In the first step (prefieldwork), data and information were collected from documents, recordings, and/or calculations. In the fieldwork, the primary data collection was conducted by interviewing the Gouyave's citizens, government's institutions, and field observations. Then, the secondary data were obtained from recorded data, such as from Maurice Bishop International Airport (MBIA) for the daily rainfall data. After the completed data has been obtained, they were compiled and prepared for analyzing and creating flood modeling using OpenLISEM software.

In order to reduce the uncertainty of soil properties value like initial soil moisture, saturated hydraulic conductivity (Ksat), and porosity, flood modeling was derived in two layers. The data of soil properties were taken from field observation. The data showed that top-soils values were high since it contains abundant organic materials like roots and leaves. Thus, the two layers used in this paper; the first layer obtained from field observation and the second layer value were adapted from literature. The data needed for conducting modeling of flash-flood are presented in Table 1. 
Table 1. Data requirement for conducting modeling of flash-flood (Pratomo, 2015)

\section{Data Requirements}

1. Catchment boundaries

2. Local drain direction

3. Slope gradient area covered by rain gauges

4. Sub-outlets and outlet location

5. Daily rainfall data
Data Source

DEM Map which is created from topographic map

Secondary data taken from Maurice Bishop International Airport, Grenada

6. Channel gradient

7. Local drain direction of channel network

8. Manning's for the channel

Field Observation

9. Channel cross section shape

10. Width of channel scalar

11. Surface roughness (Manning's $n$ )

12. Random roughness (RR)

Literature

13. Saturated volumetric soil moisture content (Thethas)

14. Saturated hydraulic conductivity (Ksat)

Laboratory Test

15. Soil depth

16. Initial volumetric soil moisture content (Thethal)

17. Leaf area index (LAI)

18. Fraction of soil covered by vegetation (PER)

Field Observation

19. Vegetation height $(\mathrm{CH})$

Gouyave watershed is a part from 12 largest watersheds in Grenada, Caribbean Island. It is located in the north-west of Grenada, included in St. John Parish (see Figure 2). Total area of Gouyave watershed area is $8.39 \mathrm{~km}^{2}$. The main river in this watershed is Charlotte River dividing Gouyave town into two areas in the downstream.

Figure 2. (a) Orientation map of Grenada and (b) Location of Gouyave watershed (Pratomo et al., 2016)
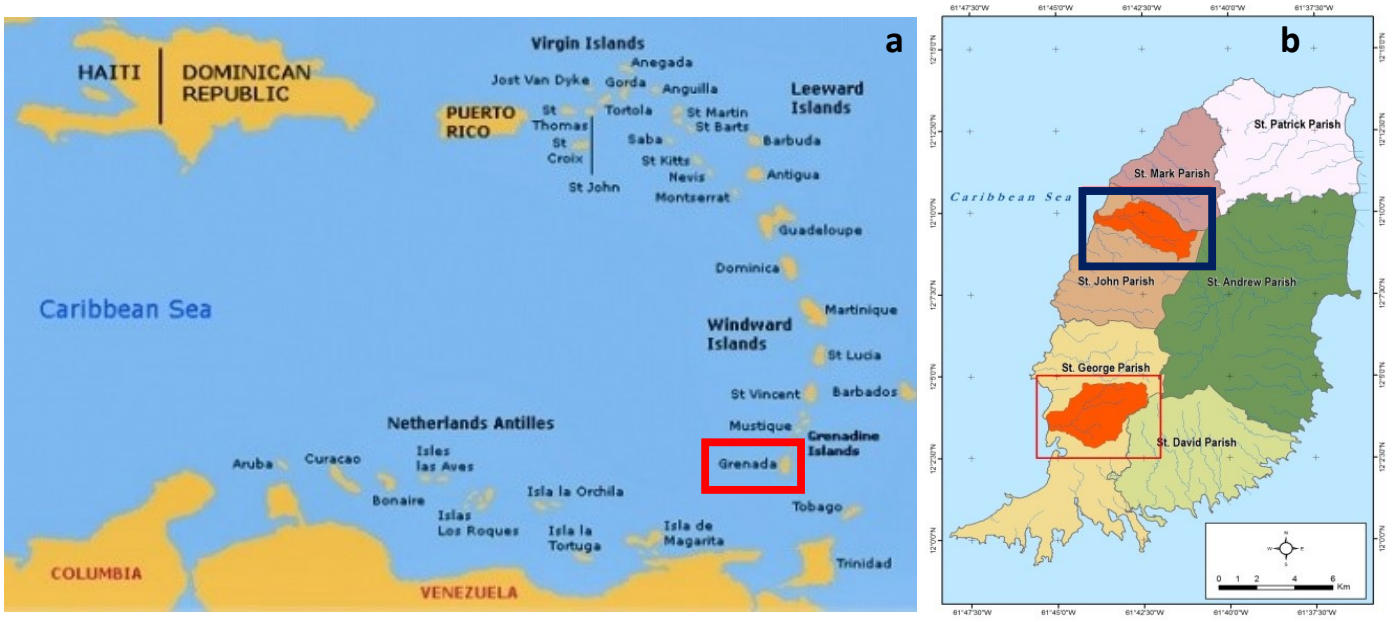

Most of areas in Gouyave watershed are mainly dominated with highlands, mountain peaks, and deep narrow valleys. They are located in area with elevation more than $200 \mathrm{~m}$ above sea level, mostly in southern parts and eastern parts of Gouyave. The highest point in Gouyave watershed located in 690 meters above sea level. The slope category class 5 - steep (25-55\%) is dominant covering $3,348 \mathrm{~km}^{2}$ (39.92\%) of Gouyave watershed area.

Land-use types in Gouyave watershed are mainly dominated with natural land-use areas, such as agriculture lands, forest and mixed-trees. Forest and mixed-trees cover mostly in Gouyave upper-part areas. There is only tropical forest-type in Gouyave watershed. The tropical climate influences the 
agriculture activities in Gouyave which produce paddy, nutmegs, bananas, cocoa, and other food crops. Mixed-trees cover $4.78 \mathrm{~km}^{2}$ or $56.96 \%$ of the total area. Other land-use types existing in Gouyave watershed are built-up area, bare-land, grassland, and shrub (see Figure 3 ). The built-up areas are only $5.53 \%$ from total area and mostly located in the lower-parts of Gouyave watershed, and near coastal area. Detail characteristics of land-use in Gouyave watershed were showed in Table 2.

Table 2. Land-use in Gouyave watershed (Pratomo, 2015)

\begin{tabular}{|c|c|c|c|}
\hline \multirow{2}{*}{ No } & \multirow{2}{*}{ Land-use types } & \multicolumn{2}{|c|}{ Area } \\
\hline & & Extent $\left(\mathbf{k m}^{2}\right)$ & Percentage (\%) \\
\hline 1 & Agriculture & 0.19 & 2.26 \\
\hline 2 & Bare land & 0.05 & 0.54 \\
\hline 3 & Built-up area & 0.46 & 5.53 \\
\hline 4 & Forest & 2.44 & 29.01 \\
\hline 5 & Grass land & 0.04 & 0.49 \\
\hline 6 & Mixed-trees & 4.78 & 56.96 \\
\hline 7 & Shrub & 0.44 & 5.22 \\
\hline & Total area & 8.39 & 100.00 \\
\hline
\end{tabular}

Figure 3. The Gouyave watershed land use map (Pratomo et al., 2016)

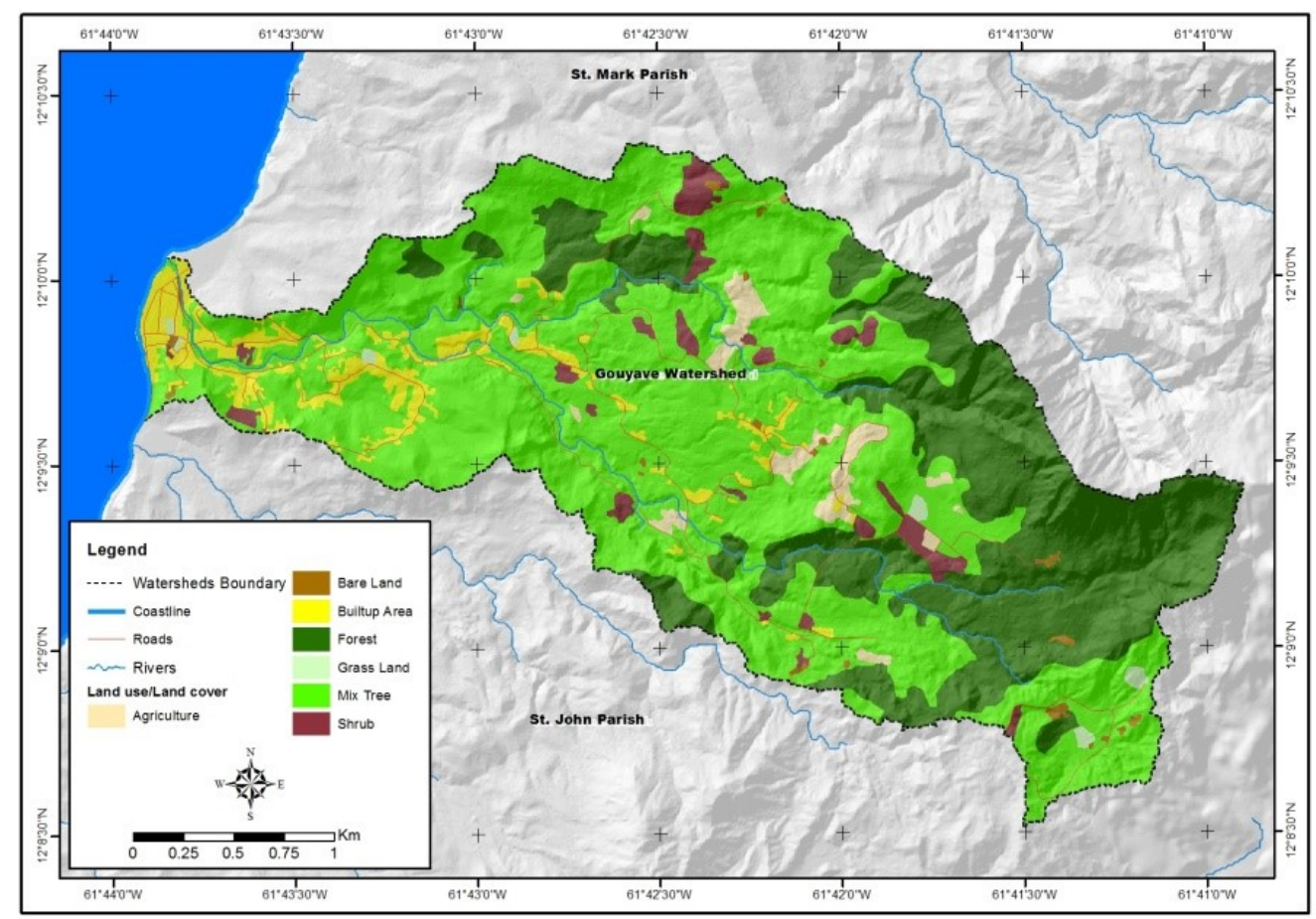

\section{RESULTS AND DISCUSSION}

\subsection{The Modeling of Flash-flood}

In modeling of flood, it is required to assess and predict the extreme rainfall and its influences to the run-off and flood events. The assessment of extreme rainfall in research area was used to estimate the rainfall return period based on the rainfall historical data using Gumbel Method. This method can be applied to measure the occurrence of extreme rainfalls probability and to identify the extreme values distribution. Table 3 shows result analysis using the Gumbel method. 
Table 3. Result of return period and maximum daily rainfall (Pratomo et al., 2016)

\begin{tabular}{crl}
$\begin{array}{c}\text { Return period } \\
\text { (years) }\end{array}$ & $\begin{array}{c}\text { Maximum Daily } \\
\text { rainfall }(\mathrm{mm})\end{array}$ & \multicolumn{1}{c}{ Remarks } \\
2 & 75.64 & $\begin{array}{l}\text { Maximum value of daily rainfall data in } 2013 \text { which included in low } \\
\text { rainfall categories. }\end{array}$ \\
\hline 5 & 110.20 & It is used for identifying sensitivity of both two watersheds in response \\
10 & 133.08 & $\begin{array}{l}\text { to flash-flood. } \\
\text { The data is used as the basic data for validation, calibration, also as an } \\
\text { event-based condition. }\end{array}$ \\
\hline 35 & 172.42 & \\
\hline
\end{tabular}

In order to analyze the flash-flood behaviors in Gouyave watershed, we used 3 return periods (2, 25, and 100 years) based on the probability of storm events and extreme events. Beside rainfall intensity, other several data were used, for instance the saturated hydraulic conductivity (Ksat), porosity, Manning's coefficient $(\mathrm{N})$, soil surface random roughness (RR), fraction of soil covered by vegetation (PER), Leaf Area Index (LAI), and vegetation height (CH).

Table 4. The physical parameters of soil and vegetation parameters (Pratomo et al., 2016)

\begin{tabular}{|c|c|c|c|c|c|c|c|}
\hline \multirow{2}{*}{ Land-use Type } & \multicolumn{7}{|c|}{ Parameters } \\
\hline & Ksat (mm/hr) & Porosity & $\mathbf{N}(\mathrm{cm})$ & $R R(\mathrm{~cm})$ & PER & $\mathrm{CH}(\mathrm{m})$ & LAI \\
\hline Agriculture & 10.71 & 0.585 & 0.08 & 0.2 & 0.35 & 4 & 1.08 \\
\hline Bare land & 12.86 & 0.495 & 0.023 & 0.05 & 0.2 & 0.05 & 0.56 \\
\hline Built-up area & 10.00 & 0.400 & 0.03 & 0.05 & 0.1 & 3 & 0.263 \\
\hline Forest & 69.64 & 0.578 & 0.1 & 0.5 & 0.8 & 13 & 4.02 \\
\hline Grass land & 19.29 & 0.580 & 0.023 & 0.2 & 0.85 & 0.5 & 4.74 \\
\hline Mix tree & 42.86 & 0.554 & 0.1 & 0.5 & 0.7 & 10 & 3.01 \\
\hline Shrub & 15.96 & 0.510 & 0.04 & 0.2 & 0.4 & 1.2 & 1.28 \\
\hline Road & 0 & 0 & 0.001 & 0.05 & 0 & 0 & 0 \\
\hline Water & 0 & 0 & 0.033 & 0.01 & 0 & 0 & 0 \\
\hline
\end{tabular}

Table 4 shows the characteristics of physical parameters based on land-use types. From those physical parameters, Ksat is the most sensitive parameters to flash-flood characteristics (Pratomo, 2015). Ksat is defined as water rates to infiltrate the soil. Ksat showed high value for natural land-use type like mixed-tree or forest, 42.86 and $69.64 \mathrm{~mm} / \mathrm{hr}$, respectively. Ksat's high impact to flood probability is in line with some former assessments and experiments about flood modeling (De Roo \& Jetten, 1999; Prachansri, 2007).

The model calibration of flash-flood was conducted by reducing the deviation between the result of flashflood modeling and the flash flood data from observation, flash-flood extent and equally flash-flood depth. Flood depth data were adapted from the flash-flood events in 2011. Then, the calibration result was evaluated using Bias and Root Means Square Error (RMSE) model. Based on the model calibration, the result of Bias and RMSE values were 0.123 and 0.303 , respectively. Both of them are the lowest data and nearly zero which means that the flash-flood modeling is accurate and has good performance.

Bias was calculated with:

$$
\frac{\sum_{i=1}^{n}\left(y_{i}-x_{i}\right)}{n}
$$


Where:

$\mathrm{n} \quad$ : total number of observations

$\mathrm{x}_{1} \quad$ : the observed value

$\mathrm{y}_{1}$ : the model-simulated value

Root Mean Square Error (RMSE) was calculated with:

$$
\sqrt{\frac{\sum_{i=1}^{n}\left(y_{i}-x_{i}\right)^{2}}{n-1}}
$$

Where:

$\mathrm{n} \quad$ : total number of observations

$\mathrm{x}_{1} \quad$ : the observed value

$\mathrm{y}_{1}$ : the model-simulated value

\subsection{Flash-flood Characteristics in Gouyave Watershed}

Flash-flood characteristics were developed using different return periods. Three scenarios of return periods have been selected, such as 2, 35, and 100 years. Flash-flood model comparison was conducted to analyze the flood characteristics in Gouyave watershed area, such as peak discharge, total discharge, average discharge, maximum flood duration, maximum flood depth, maximum flood propagation, flood volume, and flood extent.

Table 5. Comparison of flash-flood characteristics in Gouyave watershed in different return periods (Analysis, 2015)

\begin{tabular}{|c|c|c|c|}
\hline Flash-flood characteristics & $\begin{array}{l}2 \text { years } \\
\text { return period }\end{array}$ & 35 years return period & 100 years return period \\
\hline Peak discharge $\left(\mathrm{m}^{3} / \mathrm{s}\right)$ & 3.89 & 110.99 & 150.59 \\
\hline $\mathrm{Q} / \mathrm{P}(\%)$ & 3.26 & 27.21 & 35.60 \\
\hline Total discharge $\left(\mathrm{m}^{3}\right)$ & $20,791.63$ & $387,064.16$ & $579,248.98$ \\
\hline Average discharge $\left(\mathrm{m}^{3}\right)$ & $2,478.14$ & $46,133.98$ & $69,040.40$ \\
\hline Max flash-flood duration (min) & 0.00 & 345.00 & 350.00 \\
\hline Max flash-flood depth (m) & 0.00 & 1.74 & 2.25 \\
\hline Average flash-flood depth (m) & 0.00 & 0.17 & 0.40 \\
\hline Max flash-flood propagation (min) & 0.00 & 86.00 & 112.00 \\
\hline Flash-flood volume $\left(\mathrm{m}^{3}\right)$ & 0.00 & $12,805.56$ & $42,803.23$ \\
\hline Flash-flood area $\left(\mathrm{m}^{2}\right)$ & 0.00 & $41,600.00$ & $94,400.00$ \\
\hline
\end{tabular}

Table 5 shows that flash-flood do not occur in 2 years return period. Gouyave watershed areas are safe from flash-flood. This condition is due to the low rainfall intensity in 2 years return period. Gouyave watershed responses to flash-flood in 35 and 100 years return period. Peak discharge in Gouyave watershed is extremely high, specifically in 35 and 100 years return periods. The flash-flood duration of run-off is longer with lower run-off volume (Q/P). The overflow water (peak discharge) on Gouyave's channel is increasing in 35 and 100 years return period. It makes flood events in 35 and 100 years return periods will be more massive.

The maximum flood depth will be increased from $1.74 \mathrm{~m}$ in 35 years return period becomes $2.25 \mathrm{~m}$ in 100 years return period (Figure 4). However, average flood depth in 35 and 100 years return periods are only 0.17 and $0.40 \mathrm{~m}$, respectively. It means that most of flood inundation areas in Gouyave are swamped 
below $0.5 \mathrm{~m}$. The typical dominating natural land-use which have higher values of Ksat (saturated hydraulic conductivity) can infiltrate run-off well.

Figure 4. Flood-depth in Gouyave watershed at (a) return period of 35 years and (b) return period of 100 years (Analysis, 2015)
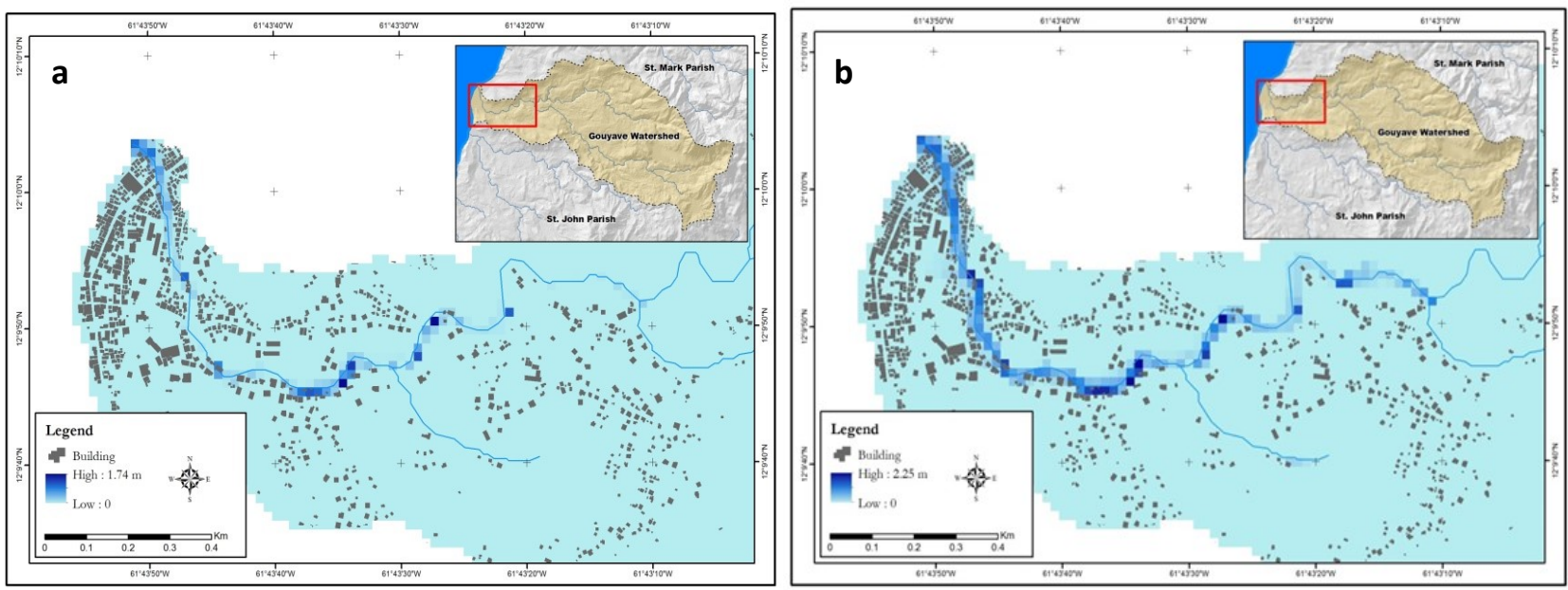

The maximum flood duration in Gouyave watershed in 35 and 100 years return periods is longer (until 350 minutes) compared to those two years return period (Figure 5). It can be explained by the longer and narrower basin shape in the upperparts of Gouyave watershed (Figure 6). In the narrower and longer basin, water from multiple locations is less likely to reach the downstream areas at the same time. It makes flood propagation time in Gouyave watershed is slower, but occurring flood inundated this areas can go for a long time with low flood depth.

Figure 5. Flood duration time in Gouyave watershed at (a) return period of 35 years and (b) return period of 100 years (Analysis, 2015)
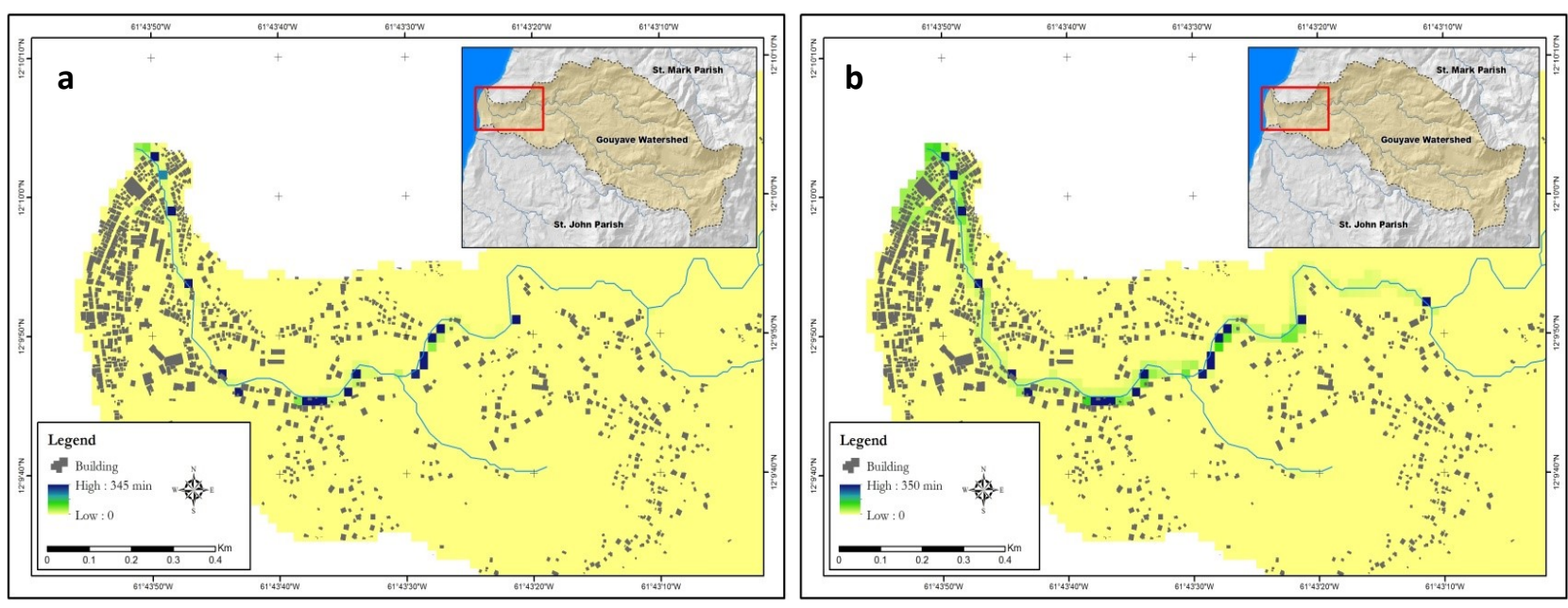

Beside the basin shape, the urban development correspondingly influences the susceptibility of flash-flood. Gouyave watershed is less urbanized. The characteristics of Gouyave watershed areas are dominated with typical natural land-use, like agriculture lands, forest, and also mixed-trees. Those types of land-use will keep the water infiltration capacity into the soil, and the soil will absorb the run-off. Human interventions and soil compaction process using heavy machines in the build-up areas affect the soil structures and soil pores to be more compact and lead the decreasing of Ksat value. Inversely, natural land-use can increase 
Ksat value. If the Ksat value is higher, the potential of run-off water will be less. It makes flood propagation time and flood depth lower.

Figure 6. Basin-shape of Gouyave watershed (Pratomo, 2015)

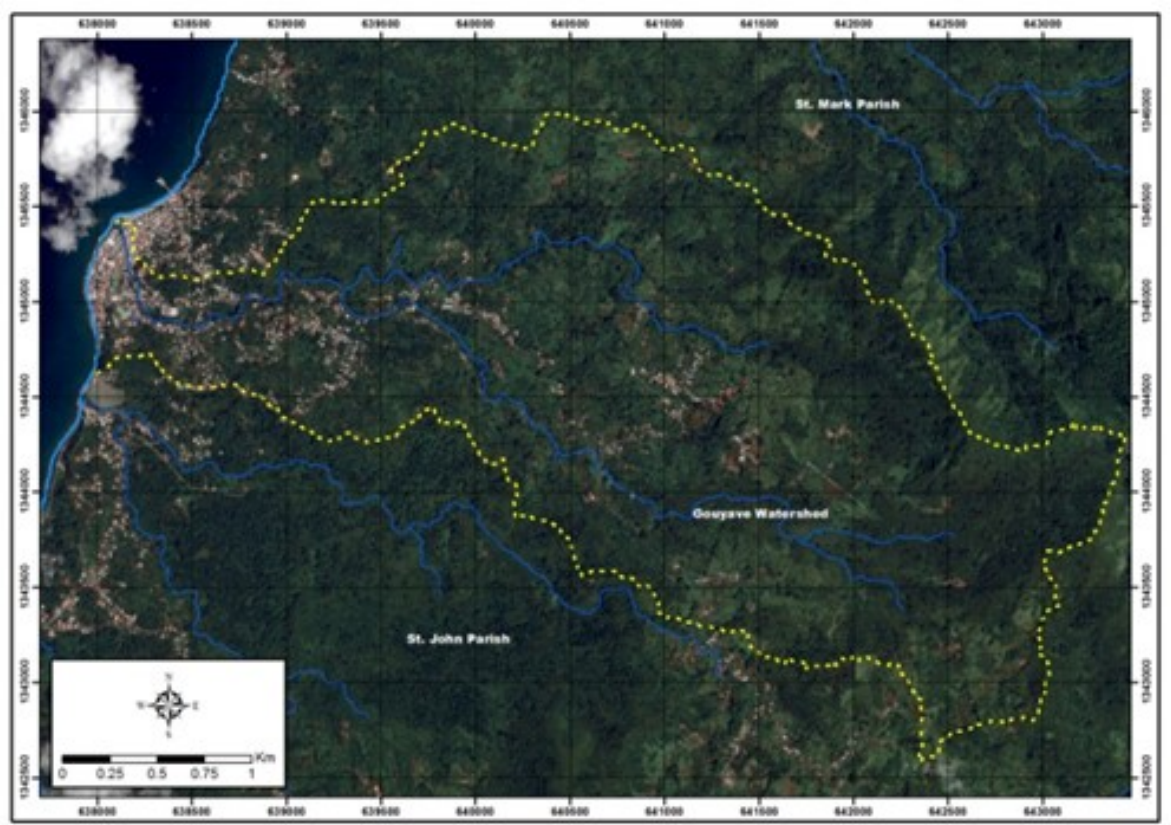

\section{CONCLUSION}

Land-use types have a high influence on flash-flood events. A rural area which is characterized with less urbanized and more natural land-use types has a lower response to flash-flood, as in the Gouyave watershed. Flash-flood has extreme peak discharge in 35 and 100 years return periods. Flash-flood will occur in long time duration, but flood propagation time is slower due to the narrower and longer Gouyave's basin shape. Also, the average of flood depth in most of Gouyave inundated areas is low (below $0.5 \mathrm{~m}$ ). It indicates that flash-flood in Gouyave watershed is less massive.

\section{REFERENCES}

Bodoque, J. M., et al. (2016). Improvement of resilience of urban areas by integrating social perception in flash-flood risk management. Journal of Hydrology, 541, 665-676. http://doi.org/10.1016/ j.jhydrol.2016.02.005

Cao, S., et al. (2008). Modeling on flash flood disaster induced by bed load. Transactions of Tianjin University, 14(4), 296-299. http://doi.org/10.1007/s12209-008-0050-6

Cooper, V., \& Opadeyi, J. (2006). Flood hazard mapping of st. Lucia. Retrieved from http://www.caribank.org/wp-content/uploads/2012/03/stlucia-final-flood-hazard-report.pdf

Creutin, J.-D., \& Borga, M. (2003). Radar hydrology modifies the monitoring of flash-flood hazard. Hydrological Processes, 17(7), 1453-1456. http://doi.org/10.1002/hyp.5122

De Roo, A. P., \& Jetten, V. (1999). Calibrating and validating the LISEM model for two data sets from the Netherlands and South Africa. CATENA, 37(3-4), 477-493. http://doi.org/10.1016/S03418162(99)00034-X

Gaitan, S., ten Veldhuis, M., \& van de Giesen, N. (2015). Spatial Distribution of Flood Incidents Along Urban Overland Flow-Paths. Water Resources Management, 29(9), 3387-3399. http://doi.org/10.1007/ s11269-015-1006-y

GFDRR. (2010). Disaster Risk Management in Latin America and the Caribbean Region. Retrieved from http://www.gfdrr.org/sites/gfdrr.org/files/DRM_LAC_CountryPrograms.pdf

Jetten, V. (2014). A brief guide to openLISEM. Electronic document.

Karagiorgos, K., et al. (2016). Integrated flash flood vulnerability assessment: Insights from East Attica, Greece. Journal of Hydrology, 541, 553-562. http://doi.org/10.1016/j.jhydrol.2016.02.052 
Kourgialas, N. N., \& Karatzas, G. P. (2011). Flood management and a GIS modelling method to assess floodhazard areas-a case study. Hydrological Sciences Journal, 56(2), 212-225. http://doi.org/10.1080/ 02626667.2011 .555836

Kundzewicz, Z. W., et al. (2014). Flood risk and climate change: global and regional perspectives. Hydrological Sciences Journal, 59(1), 1-28. http://doi.org/10.1080/02626667.2013.857411

Marchi, L., et al. (2010). Characterisation of selected extreme flash floods in Europe and implications for flood risk management. Journal of Hydrology, 394(1-2), 118-133. http://doi.org/10.1016/ j.jhydrol.2010.07.017

Mhonda, A., \& others. (2013). Evaluating flash flood risk reduction strategies in built-up environment in Kampala. University of Twente.

Niles, E. (2010). Grenada disaster vulnerability reduction project. Retrieved from http://www.gov.gd/ egov/docs/other/DVRP_EIA_March_2011.pdf

Patra, J. P., Kumar, R., \& Mani, P. (2016). Combined Fluvial and Pluvial Flood Inundation Modelling for a Project Site. Procedia Technology, 24, 93-100. http://doi.org/10.1016/j.protcy.2016.05.014

Portugués-Mollá, l., et al. (2016). A GIS-Based Model for the analysis of an urban flash flood and its hydrogeomorphic response. The Valencia event of 1957. Journal of Hydrology, 541, 582-596. http://doi.org/10.1016/j.jhydrol.2016.05.048

Prachansri, S. (2007). Analysis of soil and land cover parameters for flood hazard assessment: a case study of the Nam Chun watershed, Phetchabun, Thailand. In Earth Systems Analysis. International Institute for Geo-information Science and Earth Observation (ITC) Enschede, The Netherlands.

Pratomo, R. A. (2015). Flash flood behaviour on a small caribbean island: a comparison of two watersheds on grenada. MSc thesis, Applied Earth Science-Natural Hazard and Disaster Risk Management. ITC, Utrecht University, the Netherlands.

Pratomo, R. A., Jetten, V., \& Alkema, D. (2016). A comparison of flash flood response at two different watersheds in Grenada, Caribbean Islands. IOP Conference Series: Earth and Environmental Science, 29, 12004. http://doi.org/10.1088/1755-1315/29/1/012004

Santangelo, N., et al. (2011). Flood susceptibility assessment in a highly urbanized alluvial fan: the case study of Sala Consilina (southern Italy). Natural Hazards and Earth System Science, 11(10), 2765-2780. http://doi.org/10.5194/nhess-11-2765-2011

The Caribbean Disaster Emergency Response Agency (CDERA). (2003). Status of hazard maps vulnerability assessments and digital maps. Retrieved from http://www.eird.org/wiki/images/Hazards_maps Vulnerability_maps_Grenada.pdf

Yin, J., et al. (2016). Evaluating the impact and risk of pluvial flash flood on intra-urban road network: A case study in the city center of Shanghai, China. Journal of Hydrology, 537, 138-145. http://doi.org/10.1016/j.jhydrol.2016.03.037 